Planck

Institute for

Ornithology

in Seewiesen

Germany, and his

team analysed videos

of Natterer's bats

(Myotis nattereri;

pictured) feeding on Musca

domestica flies on a cowshed

ceiling. Thousands of lone

flies walked across the area

without being attacked.

However, copulating pairs

were attacked $5.3 \%$ of the

time. Bats also attacked

loudspeakers playing the

distinctive ultrasound buzzing

produced by copulating flies.

This is the first identified

mechanism that supports

theories that copulation can

leave animals more vulnerable to attack.

Curr. Biol. 22, R563-R564 (2012)

\section{ARCHAEOLOGY}

\section{Modern thinking gets older}

Modern human behaviour underlying cultural innovations such as language and art might have begun in southern Africa thousands of years earlier than assumed.

Evidence for symbolic behaviour, such as shell beads, appeared at least 80,000 years ago in southern Africa. This behaviour then seemingly disappeared and did not return until roughly 20,000 years ago - when humans with cultural links to modern San huntergatherers began to produce engraved bones and other complex artefacts.

However, Francesco d'Errico at the University of Bordeaux in France, Paola Villa at the University of Colorado in Boulder and their teams suggest that antecedents to San culture in fact appeared much earlier. Radiocarbon dating of seashell and ostrich eggshell beads (pictured), complex resins and an ochre-stained point previously excavated from Border Cave in South
Africa suggests that the artefacts are up to 44,000 years old. Around this time, humans living near Border Cave also began to produce doublefaced stone blades and flint arrow points - consistent with the emergence of modern symbolic behaviour, the authors say.

Proc. Natl Acad. Sci. USA http://dx.doi.org/10.1073/ pnas.1204213109; http://dx.doi. org/10.1073/pnas.1202629109 (2012)

\section{MEDICINE}

\section{Neighbours join the resistance}

Normal cells near cancerous ones can support their malignant neighbours by secreting proteins in response to anticancer drugs.

Peter Nelson at the Fred Hutchinson Cancer Research Center in Seattle, Washington, and his team found that chemotherapy triggered benign cells near prostate tumours to secrete a signalling protein called WNT16B. This promoted tumour growth and could help tumours to become resistant to therapy. Targeting the regulators of WNT16B, or other components of the tumour microenvironment, could be routes to developing anti-resistance drugs.

Nature Med. http://dx.doi. org/10.1038/nm.2890 (2012)

\section{BIOLOGY \\ Pregnancy alters gut microbes}

Pregnancy triggers a radical shift in human gut microflora, moving the body towards a diabetes-like condition.

Ruth Ley at Cornell

University in Ithaca, New York, and her team analysed the faecal bacteria of 91 pregnant women. During the first trimester, these women's bacterial populations were

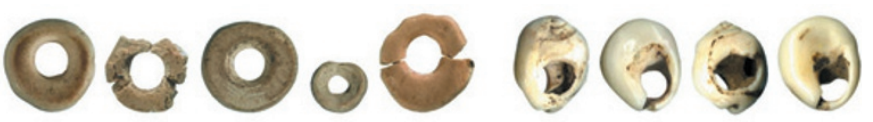

similar to each other and to those of non-pregnant women. But by the third trimester, there were marked differences between the mothers-to-be, and their average gut make-up resembled that seen in a mouse model of metabolic syndrome - a collection of symptoms linked to diabetes.

When the microbiota from third-trimester women were transferred into mice, the animals gained more fat and became less sensitive to insulin than did mice that received first-trimester microbes. Mammals can manipulate their gut biology to trigger changes beneficial to a developing fetus, the researchers suggest.

Cell 150, 470-480 (2012)

For a longer story on this research, see go.nature.com $/ 4 v 7 \mathrm{cht}$

\section{MATERIALS}

\section{SLIPS blitz biofilms}

Coating solids with immobilized liquids could help to deal with dangerous bacterial biofilms.

Many bacterial species form durable slimes that can cover everything from
The most viewed papers in science

IEUROBIOLOGY

Growing evidence suggests that the

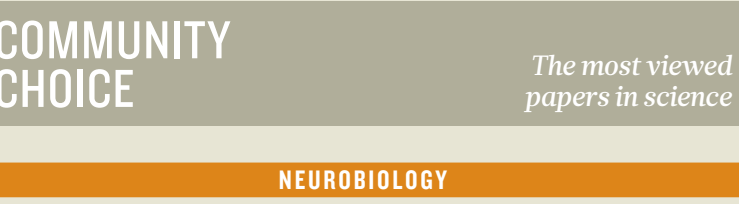

\title{
Diabetes drug boosts neuron growth
}

$$
\begin{aligned}
& \begin{array}{l}
\text { mammalian brain recruits adult neural } \\
\text { onw-ll-stem-cell } \\
\text { in July } \\
\text { or injured neurons. Drugs that can spur on } \\
\text { this recruitment are highly sought after. }
\end{array} \\
& \text { One candidate is the widely used diabetes drug metformin, } \\
& \text { which activates an enzyme called aPKC. In the brain, this } \\
& \text { protein's action on another protein, CBP, is essential for optimal } \\
& \text { specialization of neural precursor cells. } \\
& \text { Freda Miller at the Hospital for Sick Children in Toronto, } \\
& \text { Canada, and her team showed that metformin also activated } \\
& \text { the aPKC-CBP pathway in cultured mouse and human } \\
& \text { neural precursors, promoting neuron generation. Moreover, } \\
& \text { it enhanced the generation of new neurons in the brains of live } \\
& \text { adult mice. Crucially, the change seemed to confer a benefit: } \\
& \text { adult mice treated with metformin showed better spatial- } \\
& \text { memory formation in a water maze compared with controls. } \\
& \text { Cell Stem Cell 11, 23-35 (2012) }
\end{aligned}
$$
ive 